NBER WORKING PAPER SERIES

\title{
THE EFFECT OF EDUCATION ON RELIGION: EVIDENCE FROM COMPULSORY SCHOOLING LAWS
}

\author{
Daniel M. Hungerman \\ Working Paper 16973 \\ http://www.nber.org/papers/w16973 \\ NATIONAL BUREAU OF ECONOMIC RESEARCH \\ 1050 Massachusetts Avenue \\ Cambridge, MA 02138 \\ April 2011
}

I thank Phil Oreopoulos for providing me with data. This research developed from work funded by the NIH, grant 1R03HD058947-01A1. Email the author at dhungerm@nd.edu. The views expressed herein are those of the author and do not necessarily reflect the views of the National Bureau of Economic Research.

NBER working papers are circulated for discussion and comment purposes. They have not been peerreviewed or been subject to the review by the NBER Board of Directors that accompanies official NBER publications.

(C) 2011 by Daniel M. Hungerman. All rights reserved. Short sections of text, not to exceed two paragraphs, may be quoted without explicit permission provided that full credit, including $\bigcirc$ notice, is given to the source. 
The Effect of Education on Religion: Evidence from Compulsory Schooling Laws

Daniel M. Hungerman

NBER Working Paper No. 16973

April 2011

JEL No. I20,I28,Z12

\begin{abstract}
$\underline{\text { ABSTRACT }}$
For over a century, social scientists have debated how educational attainment impacts religious belief. In this paper, I use Canadian compulsory schooling laws to identify the relationship between completed schooling and later religiosity. I find that higher levels of education lead to lower levels of religious participation later in life. An additional year of education leads to a 4-percentage-point decline in the likelihood that an individual identifies with any religious tradition; the estimates suggest that increases in schooling can explain most of the large rise in non-affiliation in Canada in recent decades.
\end{abstract}

Daniel M. Hungerman

Department of Economics

University of Notre Dame

439 Flanner Hall

Notre Dame, IN 46556-5602

and NBER

dhungerm@nd.edu 


\section{Introduction}

Education and religion represent two of the dominant institutions of human society. Each has been shown to have large impacts on a range of individual outcomes; for example, educational attainment has been linked to increases in civic participation (Dee, 2004), health (Silles, 2009) and adult wages (Card, 1999); and religious participation has been linked to charitable giving (Andreoni, 2006), voting (Gerber, Gruber, Hungerman, 2010), lower levels of risky behavior (Hungerman, 2010), and better health (Johnson, Tompkins, Webb, 2002). Both modern and developing societies have seen large gains in educational attainment in recent decades, and social scientists have frequently (and sometimes famously) predicted that such gains may impact religion. But there is little compelling evidence to substantiate or refute these claims.

Indeed, prior economic work has shown that the relationship between education and religion is confounding. Many studies regressing a measure of religiosity on a set of individual controls have found a positive relationship between education and religion. While this may be surprising to those who do not regularly study religion, this positive relationship is in fact a much-noted norm in the literature (Iannacconne, 1998). But this positive relationship is sensitive to the source of variation used in the data for identification. For example, an analysis of trends in education and religion typically indicates a negative relationship, as many countries have seen declines in religiosity that are concomitant with educational gains; the coincidence of these trends has also been noted in past work (Hout and Fischer, 2002). Recent rigorous investigations on the relationship between education and religion have not clarified the matter. A number of studies suggest a positive relationship between religion and education (Gruber, 2005; McCleary and Barro 2006a; Meyersson, 2010). But other research has suggested that religious participation may be negatively associated with education (Iannaccone, 1992; Deaton, 2009).

A key challenge in this area is that educational attainment reflects individual characteristics and incentives that may themselves impinge on religious participation. Rather than looking at simple crosssectional or time-series variation in survey data, an ideal way to approach this topic would be to identify two comparable groups of individuals, induce one group (the “treatment” group) to obtain more 
education, and then observe whether religiosity was subsequently different between the two groups. This is the spirit of the approach I take in this paper.

I exploit historic changes in compulsory schooling laws in Canada for my treatment. Prior work has shown that these laws, which compelled children to attend school if they were below a certain age, led to immediate gains in education and had large impacts on lifetime earnings and occupational choice (Oreopoulos, 2006a, b). Importantly, the Canadian Census asks individuals about religious participation; it is a large dataset where education and religiosity can both be observed. Using the Canadian census, I can thus explore whether individuals compelled to attend school longer report different religious participation than other individuals. The results indicate that they do.

I find evidence that religious participation, as measured by the fraction of Canadians reporting any religious affiliation at all, is negatively associated with educational attainment. The estimates suggest that, all else equal, one extra year of schooling leads to a 4 percentage-point increase in the likelihood that an individual reports having no religious affiliation; a reasonably large effect. Results broken down by religious tradition are somewhat imprecise, but suggest that most of the rise in non-affiliation is driven by a decline in Christian-but-not-Catholic participation. The effects of the laws are not driven by any particular Canadian province. The results suggest that gains in educational attainment can explain over half of the striking rise in non-affiliation seen in Canada during the past half century.

These findings provide compelling evidence that education leads to secularization, a result that stands in contrast with most prior research. Further, these results are also informative for work on compulsory schooling laws. As prior work has found beneficial effects from religious participation, the results here are noteworthy in that they identify a possibly injurious effect—a decrease in religiosity— from compulsory schooling laws, where almost all prior work has identified strong benefits from these laws. The findings here thus suggest that the direct effect of education on outcomes, net of its impact on religiosity, may be even larger than prior estimates indicate.

The remainder of the paper is organized as follows. Section 1 overviews work on the relationship between education and religion. Section 2 describes the data and the compulsory schooling laws. Section 
3 presents results. Section 4 concludes.

\section{Religion and Education}

When the 1971 Canadian Census asked respondents to name their religious affiliation, 4 percent reported that they were not affiliated with any religious tradition. By 2001, the fraction of the population that was non-affiliated had increased to 16 percent. The United States saw a similarly large rise in nonaffiliation over this time period, from 5 percent in 1972 to 14 percent in 2000. In both countries this increase coincided with educational gains in the population; in the United States average years of education grew by 2.1 years over this period and in the Canadian samples used below the average years of completed schooling grew by 1.9 years. ${ }^{1}$

In fact, nations throughout the world have seen notable gains in education in the past half century. On average across OECD countries, the fraction of 25 to 34 year-olds with a least some upper-secondary education is 22 percentage points higher than for 55 to 64 year-olds, and the proportion of the population with at least some upper-secondary education rose from 64 percent in 1998 to 71 percent in 2008 (OECD, 2010). ${ }^{2}$ Gradstein and Nikitin (2004) document that average years of schooling throughout the world rose by more than 70 percent from 1960 to 2000 and that this rise was “universal across the world's regions.”

Some scholars have posited that educational and scientific advancement (along with the societal changes they incur) may lead to a loss of religiosity, including David Hume, John Stuart Mill, Karl Marx, Anthony Wallace, Max Weber, and Bryan Wilson. This “secularization” of society was first discussed as such by Weber and subsequently became a central concept in the study of religion. ${ }^{3}$ Understanding whether and how such secularization occurs is important not just because it would provide greater insight

\footnotetext{
${ }^{1}$ The US figures here are taken from the 1972 and 2000 waves of the General Social Survey. The sample of individuals and the education measures used in the Canadian data are discussed more below.

${ }^{2}$ The term "upper-secondary" education here is based on the International Standard Classification of Education System-1997 and typically involves more specialization than lower levels of education. The entrance age for this level of education is typically 15 or 16 years.

${ }^{3}$ See Shiner (1967), Stark (1999), and Swatos and Christiano (1999) for more on the history of the secularization hypothesis.
} 
into understanding religion, but also because religion itself has repeatedly been shown to affect numerous economically relevant activities, including civic participation, charitable giving, risky behaviors (such as heavy drinking and drug use), fertility, and criminal behavior. Studies have repeatedly shown that the predicted effect of religiosity on these outcomes is large, often larger than for any other observable covariate. $^{4}$

McCleary and Barro (2006a) suggest that there is intuition favoring both a positive and a negative relationship between education and religion. ${ }^{5}$ Given the available evidence, many scholars have concluded that secularization has not occurred (cf. Stark, 1999). Iannaccone (1998) argues, "religion is not the province of the poor or uninformed. In numerous analyses of cross-sectional survey data...most rates [of religious activity] increase with education.” A positive relationship between education and religion has been documented by, among others, Myersson (2010); Gruber (2005); McCleary and Barro (2006a); Sawkins, Seaman, and Williams (1997); Brañas-Garza and Neuman (2004); and Brown and Taylor (2007). Sacerdote and Glaeser (2001) observe that "in many multivariate regressions, education is the most statistically important factor explaining church attendance.”

But Sacerdote and Glaeser also recognize that the relationship between education and religion can change depending on one’s empirical framework and that, at the denomination level, the relationship between education and religiosity is negative. Deaton (2009) also finds an overall negative relationship between education and religion. Sander (2002) finds no relationship between education and religion. While McCleary and Barro (2006a) find a positive relationship between education and religion, McCleary and Barro (2006b) find evidence in support of secularization, and the former paper's positive result is obtained when other measures of modernization that may themselves reflect the effects of education (such as GDP) are controlled for. Moreover, McCleary and Barro (2006a) note that one should be "cautious

\footnotetext{
${ }^{4}$ A good starting place for reviewing work on religion and outcomes is Johnson, Tompkins, and Webb (2002), which surveys nearly 800 studies documenting beneficial effects of religious practice. Further, there is work suggesting that this relationship is at least partly causal, e.g., Hungerman (2010).

${ }^{5}$ For example, an increased education in the natural sciences may cause one to view religious texts as not factually true; this could lead to a loss of religious belief. Alternately, education may foster abstract thinking and tastes for social participation and these could increase one's interest in religion.
} 
about causal inferences” with their work on education given the lack of strong identification for the education effect apart from other dimensions of development. Their comment on identification is a central concern; as Sacerdote and Glaeser argue, it is likely that unobserved factors, such as tastes for networking and prosocial activities, may be associated with both an individual's educational attainment and their religious participation. Most of the above studies do not address the possible endogeneity of education when examining its relationship to religion. ${ }^{6}$

Figure 1 highlights the confounding relationship between education and religion. Panel A of Figure 1 shows the cross-sectional relationship between years of schooling attained and religious attendance in the 1972 through 2008 waves of the General Social Survey (GSS). ${ }^{7}$ (Attendance is measured on an index ranging from 0 to 8 , where higher values correspond to greater attendance; more details on the index are given below the table.) Attendance is lowest for those having completed less than 12 years of schooling and highest for those with more than 12 years of schooling. But an analysis of trends in the GSS survey produces the opposite result. Panel B of Table 1 shows that, over time, educational attainment (measured by the fraction of respondents with 12 years or more of education) has been growing, while religious attendance has been declining. Together, panels A and B suggest a severe identification problem in the data, as it is easy to document both positive and negative correlations between education and religion using a single dataset.

This study will exploit changes in Canadian compulsory schooling laws to see whether individuals' likelihood of identifying with a religious tradition is related to the legal dropout age they faced as adolescents. This study will thus use religious affiliation (or lack thereof) as the key measure of religiosity. As Hout and Fisher (2002) note, this measure of religiosity may differ from other measures,

\footnotetext{
${ }^{6}$ One exception is Sander (2002), who instruments for education using parents' education. Brown and Taylor (2007) also instrument for education using parent's education along with controls for school characteristics (e.g., whether an individual attended technical school or a private school). These studies deserve credit for addressing endogeneity. However, if confounding factors impinging on education and religion persist over generations (as would be plausible in the case of prosocial tastes, a factor considered by Sacerdote and Glaeser), or if they affect the type of education in addition to total education attained, then these approaches would be problematic.

${ }^{7}$ The GSS is a nationally-representative survey of individuals in the US conducted roughly every other year from 1973 through the present.
} 
such as self-reported belief in God. However, Hout and Fisher (2002) also note that this measure is strongly related to at least some other measures of religiosity (for example, attendance) and Glenn (1987) argues for non-affiliation as a key measure of secularization. Additionally, if positive outcomes created from religious participation are driven by formal religious proscriptions, increases in social networking, or in the creation of social capital (as suggested in Sacerdote and Glaeser, 2001; Hungerman, 2010; Putnam, 1995; and Alesina and La Ferrara, 2000), then affiliation with a formal religious group will represent a measure of religiosity especially important in promoting individual and social benefits. Thus this project will use a particular measure of religiosity, but prior work suggests that this measure is an especially useful one to consider. The next section discusses the empirical strategy and data in more detail.

\section{Data and Methods}

To consider the effects of education on religion, the data and general methodology here will follow prior work on Canadian compulsory schooling, and in particular the work of Philip Oreopoulos (2005, 2006a, 2006b). The data used are taken from the 1971, 1981, 1991, and 2001 Canadian Censuses; the data were made available by Integrated Public Use Microdata Series (IPUMS) International. ${ }^{8}$ The schooling-laws data and province-level controls were provided by Oreopoulos.

The IPUMS data provide information on an individual's age, province of birth, ${ }^{9}$ religious affiliation, and educational attainment. ${ }^{10}$ The analysis will focus on the 10 provinces of Canada; the small

\footnotetext{
${ }^{8}$ The Canadian Census was also conducted in 1976, 1986, and 1996, but these quinquenniel waves are not available from IPUMS. Regressions on education specified similarly to Oreopoulos (2006b) (who does use the quinquenniel years) yield results very close his and given the large sample size here the omission of these years should not impact the analysis. The 1971 sample is a $1 \%$ sample, the 1981 sample is $2 \%$, the 1991 sample is $3 \%$, and the 2001 sample is $2.5 \%$.

${ }^{9}$ Province of birth is used instead of province of residence to avoid concerns over endogenous migration. However, the results are similar if province of residence is used instead.

${ }^{10}$ One might wonder if other nations' compulsory schooling laws, and especially the 1947 compulsory schooling law in the United Kingdom (UK), could also be used. The 2001 UK Census included a question on religious adherence, but microdata samples of that census place respondents into age bins, preventing a convincing analysis of the 1947 law. Prior work on compulsory schooling in the UK has used non-census data, and in particular various years of the General Housing Surveys (GHS). But while the GHS does not use age bins, it does not ask about religion (nor do most other major UK datasets). The US census does not ask questions about religious adherence; the
} 
number of individuals born in the Nunavut Territory, the Yukon Territory, and the Northwest Territories are excluded. ${ }^{11}$ Individuals in the Census were asked "what is your religion" and could choose from a number of options, including "no religion.",12

Education refers to highest grade or year of education attended by an individual; this variable is top-coded and bottom coded in most census years. In particular, years of education beyond the high school level and below grade 5 are typically grouped together in the public-use data (e.g., "grade 13 or greater" and "less than grade 5"). I impute years of education above high-school as 14 and below grade 5 as 4. There are at least three reasons to expect that this should not have any impact on the results. First, the vast literature on compulsory education has repeatedly confirmed that compulsory schooling laws have no impact on post-secondary educational attainment (Card 1999; Angrist and Krueger, 1991; Oreopoulos, 2007; Clark and Royer, 2008; and others), thus the main variation in educational attainment that is lost (post-secondary attainment) is variation that is unresponsive to the laws and unimportant to the identification strategy. ${ }^{13}$ Further, the correlation between the years of education used here and the measure constructed by Oreopoulos for the census years 1981 and 1991 (i.e., the years both used in his study and in this study) is about 0.95 ; confirming that there is little systematic (or even unsystematic) variation created from truncation; Oreopoulos (2006b) also confirms little difference between public- and private-use data estimates. ${ }^{14}$ Furthermore, education regressions on specifications matching Oreopoulos'

longest running survey in America which does is the General Social Survey, but it is too recent and small to provide a robust analysis given the fact that US compulsory schooling laws are relatively old and had relatively small effects compared to other countries (Acemoglu and Angrist, 2000).

${ }^{11}$ These individuals are excluded because compulsory schooling law information is unavailable. For the 1991 and 2001 census years respondents born in Prince Edwards Island cannot be distinguished from individuals born in the three Canadian Territories and thus are omitted from the analysis. Eliminating all those born in Prince Edward Island from the analysis does not affect the results.

${ }^{12}$ In the 1981 Census, a small number of native-born individuals listing a religion other than Christian, Eastern (e.g., Hinduism or Buddhism), or Jewish were coded as having no religion. The most prominent category of misclassified individuals was probably Muslim, who accounted for less than a half of a percent of the native-born Canadian population in 1991 and likely an even smaller fraction in 1981. Repeating the below analysis without the 1981 Census yields similar and slightly larger estimates. In 2001, the census option was "no religious affiliation" instead of "no religion."

${ }^{13}$ One way to verify this is to alter the imputation and see if the results change. I redid the estimates imputing education below grade 5 as zero and above grade 13 as 17; the first-stage estimates in this case are close to those shown below, confirming that such imputation is unimportant to the estimation.

${ }^{14}$ See footnote 3 in his paper. 
produce very similar results (despite using different census years), again suggesting that the measure of educational attainment here is suitable.

The census responses will be aggregated to cells based on gender, the census year, the cohort (birth year), and the birth province, so that the unit of observation is all individuals of gender $g$ born in province $p$ in year $y$ and observed in census year $c$. The regressions below will be of the form:

$$
\text { none }_{\text {gpyc }}=\beta e d_{g p y c}+\gamma X_{g p y c}+\phi_{p}+\varphi_{y}+\theta_{c}+\vartheta_{a}+T_{p y}+\tau_{p a}+\varepsilon_{g p y c} .
$$

The variable none $e_{\text {gpyc }}$ in equation (1) denotes the fraction of all individuals in a cell who report no religious affiliation. The variable $e d_{\text {gpyc }}$ represents average years of educational attainment, and $X_{\text {gpyc }}$ represents a set of controls including a dummy for gender, the fraction of a province's population that is rural at the time a respondent was 12 years old, and the fraction of a province's workers in manufacturing at age 12. Some regressions also add in additional educational controls at age 12 including the log of school expenditures, schools per capita, and teachers per capita. ${ }^{15}$ The regressions also include a strong set of controls to account for the significant cross-sectional and time series variation in education and religious affiliation in the data. The variables $\phi_{p}, \varphi_{y}, \theta_{c}$, and $\vartheta_{a}$ represent dummies for (respectively) an individual's province of birth, year of birth, the census year in question, and an individual's age. ${ }^{16}$ The term $T_{p y}$ represents a set of province specific time trends that is linear in birth year, and $\tau_{p a}$ is a set of province specific trends that is linear in age; the regressions thus allow for differential trends over time and over ages across provinces. The approach here should thus avoid confounding the effects of the laws with either cohort effects (e.g., more recent cohorts are less religious) or age effects (younger cohorts are less religious). The term $\varepsilon_{\text {gpyc }}$ is noise.

To address the concern that unobservable determinants manifest in $\varepsilon_{\text {gpyc }}$ may be correlated with $e d_{\text {gpyc }}$, the regressions will instrument for education using a set of dummy variables denoting the age at

\footnotetext{
${ }^{15}$ Using controls as of age 10 or 14 produces similar estimates.

${ }^{16}$ One might wonder if census, year-of-birth, and age dummies are all separately identified; it is straightforward to verify that with four census years of overlapping cohorts each of these sets of dummies can be included.
} 
which an individual could legally drop out from school as of the time the individual was age 14; these are comparable to the instruments used by Acemoglu and Angrist (2000); Lleras Muney (2005); Schmidt (1996); Goldin and Katz (forthcoming); Oreopoulos, Page, and Stevens (2006); and Oreopoulos (2005, 2006a, 2006b). The regressions include individuals over age 20 and the availability of the right-hand-side controls restricts the sample to individuals born between 1919 and $1963 .{ }^{17}$ Most provinces in Canada had a change in their dropout ages over the relevant time span, although a few (British Columbia, Nova Scotia, and most notably Ontario) did not. ${ }^{18}$

Prior work (e.g., Oreopoulos, 2006b) has shown that compulsory laws are suitable instruments for education and that in practice these laws generated significant gains in Canadian educational attainment. However, one might wonder to what extent results from the Canadian education system are comparable to other countries. As in the United States, education in Canada has typically been administered at the local or provincial level, rather than at the federal level. ${ }^{19}$ Elementary education typically emphasized reading, writing, and basic mathematics. Secondary education could be academic or, for example, vocational or technical, but often included subjects such as English, Mathematics, Social Studies, religious studies (in Quebec), and Science. However, school curriculums and the structure of education varied widely over place and time and the number of years of education required before completing secondary education also varied. ${ }^{20}$

Canada is also notable in that denominationally-affiliated schools may receive revenues from government taxes. ${ }^{21}$ Government support for denominational (often Catholic) education varied widely

\footnotetext{
${ }^{17}$ Restricting the sample to even older individuals, such as those over age 25 or age 30, does not significantly alter the results.

18 The changes used here are: Alberta (raised the dropout age from 15 to 16 in 1969), Manitoba (raised the age from 14 to 16 in 1963), New Brunswick (raised the age from 12 to 16 in 1945), Newfoundland (raised the age from none to 14 in 1942, and again from 14 to 15 in 1951), Prince Edward Island (raised the age from 13 to 15 in 1938), Quebec (raised the age from 14 to 15 in 1961), and Saskatchewan (raised the age from 15 to 16 in 1964). The law changes are discussed in detail in Oreopoulos (2005).

${ }^{19}$ The federal government did play a role during the time of this study in educating some populations, such as certain Native American and Eskimo groups, or overseas personnel in Europe (Katz, 1969).

${ }^{20}$ See Katz, 1969, for a discussion of education in Canada during the period of study.

${ }^{21}$ See section 93 of the 1867 Constitution Act, sometimes referred to as the 1867 British North American Act. The constitution extended the right to public funds to denominational schools that were legally recognized at the time, although frequently this right has been granted to schools established afterwards.
} 
across provinces and over time; for example, Quebec traditionally has offered two separate school systems, one Catholic and one Protestant, which each received a proportionate share of taxpayer revenue, while British Columbia and Manitoba offered no support for denominational schools during most the period of analysis here. ${ }^{22}$ Research suggests that religious education leads to stronger religious affiliation, all else equal, (cf. Perl and Gray, 2007; Gunnoe and Moore, 2002; Himmelfarb, 1979 and 1980; Cohen 1975); if Canada’s support for religious education thus leads to an educational system conducive to religious practice it will likely bias the results towards finding a positive relationship between education and religion, which would work against the negative relationship found below.

Furthermore, there are several reasons to expect that results from Canada may be informative of other nations. In a well-known paper, Oreopoulos (2006a) uses compulsory schooling laws to estimate the return to education on wages in Canada, the United States, and the United Kingdom, and finds that the estimated returns are remarkably similar across all three settings, which suggests that the effects of education in Canada on some outcomes are comparable to effects in other nations. Furthermore, Aknin et al. (2010) argue that inclinations towards prosocial behavior, which are strongly associated with religiosity, are similar across a wide variety of nations; these researchers emphasize this fact by showing that the motivations for prosocial behavior in Canada are similar to those in Uganda, a country considerably different from Canada on most dimensions. Also, as discussed above, trends in religious affiliation in Canada in recent decades are similar to those in other countries and in particular to the United States. Thus, while the estimates here relate to a single country, prior work and basic observables suggest that this country is comparable to others in terms of religious practices and motivations and in terms of the effects of compulsory education.

\section{Results}

This section provides estimates of the relationship between education and religion; Figure 2

\footnotetext{
${ }^{22}$ Quebec has since changed some aspects of its dual-school system although these recent changes fall outside the time period of this study. For a history of denominational education in Canada, see chapter 17 in Phillips (1957).
} 
begins by presenting a simple comparison of education and religion in Quebec. The data for the figure come from the 1971, 1981, 1991, and 2001 Canadian Censuses; the figure shows two lines for individuals born in Quebec who turned age 14 between 1955 and 1965. The solid line, measured on the left axis, shows average years of educational attainment by the year an individual turned 14 . The dashed line, measured on the right axis, shows the fraction of individuals reporting no religious affiliation by the year an individual turned 14; both lines are detrended. In 1961, Quebec raised the age at which an individual could leave school from 14 to 15 . Thus, those who turned 14 in 1960 could leave school before their next birthday, while those who turned 14 in 1961 could not. The figure shows a notable and persistent jump in both educational attainment and in non-affiliation for cohorts exactly in 1961, when the law changed. The rise in educational attainment is about 0.2 years, and the rise in non affiliation is about 0.01 ; a simple Wald-style estimate from the figure would indicate that a one-year increase in educational attainment would lead to about a 5-percentage-point increase in non-affiliation.

While Figure 2 is visually compelling, one might wonder whether the figure generalizes to the rest of Canada, as Quebec's culture and educational system are in some ways distinct from other provinces. To consider law changes across time and place together, Table 1 reports first-stage regression results where the unit of observation is all individuals of the same gender, born in a particular province, in a particular year, and observed in a particular census, and the dependent variable is the average of the highest grade attended. The regressions are weighted by cell size and the robust standard errors are clustered by province and cohort (as in prior work on compulsory laws in Canada). The average level of education in the regression sample is 10.7 years.

The first column reports results from a regression where the mandatory school leaving age is reported as a linear control. The coefficient on school leaving age is positive and significant, indicating that raising the legal dropout age by one year leads educational attainment to increase by about 0.017 years. The second column adds in additional right-hand side controls for educational conditions at age 12; this does not significantly alter the estimate. Column 3 repeats the regression in column 2 but omits Quebec, now the effect is slightly larger than before. The last three columns report estimates where the 
dropout age is captured with a set of dummy variables; the omitted category is having no dropout age.

The coefficients on the dropout ages of 12 and 13 are smaller and typically not significant, while

coefficients for ages 14,15 , and 16 are larger and significant. The estimates for the age 14,15 , and 16 dummies are qualitatively similar to those reported in Table 1 of Oreopoulos (2006b); this similarity includes the decrease in magnitude in the coefficient for the age-16 dummy relative to the age-15 dummy. ${ }^{23}$ As in the first 3 columns, the removal of Quebec does not weaken the first-stage estimates.

Table 2 reports reduced-form estimates where the dependent variable is now the fraction of each cell that reports no religious affiliation; the mean of this variable is 0.085 (which corresponds to 8.5 percent). The samples and specifications in each column of Table 2 correspond to those in Table 1 . The results indicate that individuals who faced higher school-leaving ages have higher rates of non-affiliation as adults. For example, the coefficient in column 1 indicates that increasing the school-leaving age by one year raises the non-affiliation rate by 0.14 percentage points. (The magnitude of these estimates is considered more below.) As in Table 1, adding the extra controls and dropping Quebec do little to alter the results and may slightly strengthen the estimates. The last three columns again report estimates using a set of dummies for dropout age. As in Table 1, the estimates for the age 12 and age 13 dummies are smaller and/or insignificant while the age 14, 15, and 16 dummies are generally larger and statistically significant. The drop in the magnitude of the age-16 coefficient in Table 1 is again seen in the last 3 columns of Table 2.

To estimate directly the effect of educational attainment on religion, Table 3 reports two-stage-

\footnotetext{
${ }^{23}$ Acemoglu and Angrist (2000) report specifications with similar results using US data. There may be several reasons for the decline of the age-16 coefficient relative to age 15. First, the "plains provinces" which adopted an age 16 cutoff (and in particular Alberta, the largest province in the sample to adopt an age 16 cutoff) did so relatively late compared to other law changes, so that educational attainment was already relatively high; this may have lessened the potential impact of the law change. Second, dropout ages of 14 or 15 may have forced some students to enter high school who, before the law change, would have dropped out before matriculating. The most populous provinces to invoke age 16 dropout ages did so by raising the age to 16 from 15 , in which case students impacted by the laws may have already matriculated. If some individuals induced to begin high school by age 14and 15-school-leaving ages subsequently graduated, such "extensive-margin” policy effects could lead to larger estimates than changes in the school-leaving age from age 15 to 16, which only capture intensive-margin effects. Finally, as shown below, the results here are not sensitive to dropping any province that adopted an age 16 cutoff (or simultaneously dropping all observations with an age-16 dropout age).
} 
least-squares IV estimates where the school-leaving age is used to instrument for education. The first column in Table 3 reports the coefficient on education in an OLS regression. The coefficient is negative, suggesting that educational attainment lowers non-affiliation (and thus increases religious affiliation). This positive relationship between education and religion fits with most prior studies, as discussed in Section 1. However, the IV regressions in columns 2 and 3 suggest the opposite effect. Column 2 uses a linear control for the dropout age as the instrument; this specification matches column 2 in Tables 1 and 2. Column 3 uses the set of school leaving age dummies as instruments; this specification corresponds to column 4 in Tables 1 and 2.

In both cases the coefficient on education is positive and significant, suggesting that an additional year of education leads to between a 4.4 and 5.7 percentage-point increase in non affiliation. This estimated effect is strikingly similar to the basic Wald-style estimate described earlier for Figure 2, which simply considered de-trended data from Quebec. To interpret the magnitude of this coefficient, consider that from 1971 to 2001 education reported in the Census increased by about 2 years. The coefficient in column 3 suggests that non affiliation should have correspondingly increased by a little less than nine percentage points, $2 \times 4.37=8.74$. In reality, non-affiliation in Canada rose by 11.7 percentage points. The estimates in Table 3 suggest that gains in educational attainment can account for most of the large increase in non-affiliation seen in Canada over this time period.

The increase in non-affiliation must be compensated by a corresponding decline in religious affiliation; the last two columns in Table 3 investigate which religious groups see a decline as education rises. Column 4 matches the IV estimates in column 3, but now the dependent variable is the fraction of the population that is Catholic (Catholics make up about 48 percent of the sample). ${ }^{24}$ The coefficient is negative but imprecisely estimated. The last column looks at the fraction of individuals who report a Christian-but-not-Catholic affiliation (these individuals make up 41 percent of the sample); the coefficient is again negative and marginally significant, but still imprecise. Although the standard errors are large,

\footnotetext{
${ }^{24}$ As in column 3, here the set of dummies for leaving age are used to instrument education. For these regressions and those in Table 4, using the linear leaving-age controls usually produces qualitatively-similar but somewhat less precise estimates.
} 
the point estimates suggest that most of the decline in religiosity here is driven by non-Catholics. This is interesting as past work has argued that Protestant religious practice is more amenable to educational attainment (e.g., Becker and Woessman, 2009), which might lead one to predict that increased educational attainment would be especially injurious for Catholic participation. This finding may also reflect Canada's tradition of subsidizing denominational, and frequently Catholic, education with public funds. However, dropping Quebec (a province with a notably strong system of Catholic education) and redoing the estimates in columns 4 and 5 produces results that continue to suggest a stronger effect for non Catholics. $^{25}$

Table 4 presents IV results dropping each province. The estimates indicate that the results are not driven by any one province but are similar when various provinces are removed. The estimates are in every case still positive and statistically significant and range from 0.025 (when Alberta is dropped) up to 0.0567 (when Manitoba is dropped). The similarity is noteworthy given the heterogeneity across provinces in population, educational funding, educational structure, and the role of denominational schools. The estimate from dropping Quebec, by far the largest province with a policy change, is 0.0474 , which is essentially the same as the estimate in column 3 of Table 3 that includes all provinces. Clearly the results are not driven by Quebec, or any other particular province.

One might also wonder whether changes in school-leaving ages are anticipated by prior changes in education or religious affiliation. To investigate this issue, Figure 3 presents results from two regressions. The first regression redoes the first-stage regression on educational attainment in column 2 of Table 1, but includes 12 new dummy variables. Six of these dummies are "lead" dummies; they equal unity if a province will change its leaving age in 2 years, 3 years, 4 years, and so on up to 7 years. The other six dummies are "lagged” dummies, which equal unity if a province changed its leaving age 2 years ago, 3 years ago, and so on up to 7 years ago. An identical reduced-form regression was then estimated where the dependent variable was the fraction of individuals who report no religious affiliation.

\footnotetext{
${ }^{25}$ After omitting Quebec, the coefficient from a regression on Catholic adherence is -0.0165 [0.0251] and the coefficient from a regression on Christian-non-Catholic adherence is -0.0365 [0.0284].
} 
Figure 3 uses the coefficients from these lag and lead dummies to plot out predicted educational attainment and religious affiliation 7 years before and 7 years after imposing an age-14 school-leaving age (relative to no leaving age). Predicted education is given by the solid line and is measured on the left vertical axis; predicted non-affiliation is given by the dashed line and measured on the right vertical axis. The critical result in the picture is that neither education nor religion show any systematic increase or decrease before the law change. ${ }^{26}$

Overall, the results in this section indicate that educational attainment is negatively related to religiosity. An additional year of education raises the likelihood that an individual reports no religious affiliation by about 4.5 percentage points; this result is not driven by any particular province and is not driven by pre-existing trends that precede a law change. The results here suggest that the impact of educational attainment may be driven by Christian-non-Catholics becoming unaffiliated, although these results are somewhat imprecise. But the results here indicate that the strong rise in educational attainment since 1971 can explain most of the corresponding rise in non-affiliation seen over the same period.

\section{Conclusions}

This paper investigates how educational attainment affects religious affiliation later in life. Using compulsory schooling laws, the results show that higher levels of education lead to lower levels of religious affiliation later in life, a result in contrast to the basic OLS estimates and most prior work. The results indicate that educational attainment can explain most of the large rise in non-affiliation in Canada in recent years. While the study here focuses on only one area that falls under the larger literature of “secularization,” it provides unique evidence of secularization in a literature where many scholars have considered secularization to have been falsified and where few studies pursue identification rigorously.

While some prior work has suggested that the relationship between religion and education is

\footnotetext{
${ }^{26}$ Moreover, most of the coefficients on the lead dummy variables in Figure 3 are statistically insignificant as well. Of the 12 coefficients estimated before the law change (6 for education and 6 for non-affiliation); only two are statistically significant at the 10-percent level: the education coefficient 5 years before a law change, and the nonaffiliation coefficient 3 years before a law change. The rest of the lead coefficients are insignificant.
} 
likely confounded by omitted characteristics, there is no prior study which rigorously attempts to determine the direct relationship between education and religion and thus, implicitly, the first-order relationship between the confounding factors and education \& religion. The results here indicate that unobservable factors, such as tastes for civic participation or aptitude for abstract thinking, lead individuals to consume more education and more religion even as the direct effect of education on religion is negative. Alternative stories would involve spurious negative relationships between education and religion; for example "skeptical” individuals might naturally obtain more education but less religion. The results provide evidence against this “skepticism” scenario.

One implication of this work concerns the estimates in the return-to-education literature. Past work has shown that educational attainment may have beneficial impacts on outcomes such as health and civic participation; work has also found positive impacts from religion. If education lowers religiosity, and thereby reduces a key channel for producing positive outcomes, then the direct effect of education on other outcomes may be even larger than prior work suggests. However, one caveat here is that this study (and essentially all studies on compulsory education) rely on variation in secondary education for identification. It is possible that variation in higher education might have a different effect on religion. Investigations based on higher education are left for future work. 


\section{References}

Acemoglu, Daron, and Joshua Angrist (2000) "How Large Are Human Capital Externalities? Evidence from Compulsory Schooling Laws,” NBER Macroeconomics Annual.

Aknin, Lara, Christopher Barrington-Leigh, Elizabeth Dunn, John Helliwell, Robert Biswas-Diener, Imelda Kemeza, Paul Nyende, Claire Ashton-James, and Michael Norton (2010) "Prosocial Spending and Well-Being: Cross-Cultural Evidence for a Psychological Universal,” NBER working paper 16415.

Alesina, Alberto, and Eliana La Ferrara (2000) “Participation in Heterogeneous Communities,” Quarterly Journal of Economics 115(3), 847-903.

Andreoni, James (2006) "Philanthropy,” in S-C. Kolm and J. Mercier Ythier, eds., Handbook of Giving, Reciprocity and Altruism. Amsterdam: North Holland, 1201-1269.

Angrist, Joshua, and Alan Krueger (1991) "Does Compulsory School Attendance Affect Schooling and Earnings?” Quarterly Journal of Economics 106(4), 979-1014.

Brañas-Garza, Pablo, and Shoshana Neuman (2004) "Analyzing Religiosity within an Economic Framework: The Case of Spanish Catholics,” Review of Economics of the Household 2, 5-22.

Becker, Sascha, and Ludger Woessman (2009) "Was Weber Wrong? A Human Capital Theory of Protestant Economic History,” Quarterly Journal of Economics 124(2), 531-596.

Brown, Sarah, and Karl Taylor (2007) "Religion and Education: Evidence from the National Child Development Study,” Journal of Economic Behavior \& Organization 63, 439-460.

Card, David. 1999. "The Causal Effect of Education on Earnings.” In Handbook of Labor Economics 3A, Orley Ashenfelter and David Card (eds.) Chapter 30. Oxford: Elsevier.

Clark, Damon, and Heather Royer (2008) "The Effect of Education on Adult Mortality and Health: Evidence from the United Kingdom,” Working Paper.

Cohen, Steven (1974) "The Impact of Jewish Education on Religious Identification and Practice," Journal for the Scientific Study of Religion 36(3/4), 316-326.

Deaton, Angus (2009) “Aging, Religion, and Health,” Working paper.

Dee, Thomas (2004) “Are there Civic Returns to Education?” Journal of Public Economics 88, 16971720.

Gerber, Alan, Jonathan Gruber, and Daniel Hungerman (2010) "Does Church Attendance Cause People to Vote? Using Blue Laws’ Repeal to Estimate the Effect of Religiosity on Voter Turnout," Working Paper

Glenn, Norval (1987) “The Trend in 'No Religion’ Respondents to U.S. National Surveys, Late 1950s to Early 1980s,” The Public Opinion Quarterly 51(3), 293-314.

Goldin, Claudia, and Lawrence Katz (forthcoming) "Mass Secondary Schooling and the State: the Role of State Compulsion in the High School Movement," in D. Costa and N. Lamoreaux, Understanding Long-run Economic Growth (Cambridge University Press).

Gradstein, Mark, and Denis Kisitin (2004) “Educational Expansion: Evidence and Interpretation,” World Bank Policy Research Working paper 3245.

Gruber, Jonathan (2005) "Religious Market Structure, Religious Participation, and Outcomes: Is Religion Good for You?” Advances in Economic Analysis \& Policy 5(1), article 5.

Gunnoe, Marjorie, and Kristin Moore (2002) "Predictors of Religiosity among Youth Aged 17-22: A Longitudinal Study of the National Survey of Children," Journal for the Scientific Study of Religion 41(4), 613-622.

Himmelfarb, Harold (1980) "The Study of American Jewish Identification: How it is Defined, Measured, Obtained, Sustained, and Lost,” Journal for the Scientific Study of Religion 19(1), 48-60.

Himmelfarb, Harold (1979) “Agents of Religious Socialization Among American Jews,” The Sociological Quarterly 20(4), 477-494.

Hout, Michael and Fisher Claude Fischer (2002) "Why More Americans Have No Religious Preferences: Politics and Generations,” American Sociological Review 67(2), 165-190.

Hungerman, Daniel (2010) "Does Religious Proscription Cause People to Act Differently? Evidence from 
a Theory-Based Test,” Working paper.

Iannaccone, Laurence (1992) "Sacrifice and Stigma: Reducing Free-Riding in Cults, Communes, and Other Collectives,” Journal of Political Economy 100(2), 271-297.

Iannaccone, Laurence (1998) "Introduction to the Economics of Religion," Journal of Economic Literature 36(3), 1465-1495.

Johnson, Byron, Ralph Tompkins, and Derek Webb (2002) "Objective Hope: Assessing the Effectiveness of Faith-Based Organizations: A Review of the Literature,” report for the Center for Research on Religion and Urban Civil Society.

Katz, Joseph (1969) Society, Schools, and Progress in Canada. (Oxford: Pergamon Press).

Lleras-Muney, Adriana (2005) "The Relationship Between Education and Adult Mortality in the U.S.” Review of Economic Studies 72, 189-221.

McCleary, Rachel and Robert Barro (2006a) "Religion and Political Economy in an International Panel," Journal for the Scientific Study of Religion 42(2), 149-175.

McCleary, Rachel, and Robert Barro (2006b) “Religion and Economy,” Journal of Economic Perspectives 20(2), 49-72.

Meyersson, Erik (2010) "Islamic Rule and the Emancipation of the Poor and Pious," working paper.

Oreopoulos, Philip, Marianne Page, and Ann Stevens (2006) “The Intergenerational Effects of Compulsory Schooling,” Journal of Labor Economics 24(4), 729-760.

Oreopoulos, Philip (2007) "Do Dropouts Drop Out Too Soon? Wealth, Health, and Happiness from Compulsory Schooling,” Journal of Public Economics 91, 2213-2229.

Oreopoulos, Philip (2006a) "Estimating Average and Local Average Treatment Effects of Education when Compulsory Schooling Laws Really Matter,” American Economic Review 96(1), 152-175.

Oreopoulos, Philip (2006b) “The Compelling Effects of Compulsory Schooling: Evidence from Canada,” Canadian Journal of Economics 39(1), 22-52.

Oreopoulos, Philip (2005) "Canadian Compulsory School Laws and their Impact on Educational Attainment and Future Earnings,” Analytical Studies Branch Research Paper No. 251, Statistics Canada.

Organisation for Economic Cooperation and Development (OECD) (2010) Education at a Glance 2010: OECD Indicators. Published by the OECD.

Perl, Paul and Mark Gray (2007) “Catholic Schooling and Disaffiliation from Catholicism,” Journal for the Scientific Study of Religion 46(2), 269-280.

Phillips, Charles (1957) The Development of Education in Canada. (Toronto: W. J. Gage and Company Limited)

Putnam, Robert (1995) “Bowling Alone: America’s Declining Social Capital” Journal of Democracy 6(1), 65-78.

Sacerdote, Bruce and Edward Glaeser (2001) “Education and Religion,” NBER Working paper 8080.

Sander, William (2002) "Religion and Human Capital,” Economics Letters 75, 303-307.

Sawkins, John, Paul Seaman, and Hector Williams (1997) “Church Attendance in Great Britain: And Ordered Logit Approach,” Applied Economics 29, 125-134.

Schmidt, Stefanie (1996) "School Quality, Compulsory Education Laws, and the Growth of American High School Attendance, 1915-1935,” PhD dissertation, MIT.

Shiner, Larry (1967) “The Concept of Secularization in Empirical Research,” Journal for the Scientific Study of Religion 6(2), 207-220.

Silles, Mary (2009) "The Causal Effect of Education on Health: Evidence from the United Kingdom,” Economics of Education Review 28, 122-128.

Stark, Rodney (1999) “Secularization, R.I.P.” Sociology of Religion 60(3), 249-273.

Swatos, William, and Kevin Christiano (1999) "Introduction-Secularization Theory: The Course of A Concept,” Sociology of Religion 60(3), 209-228. 


\section{Figure 1: \\ Religion and Education in the GSS}

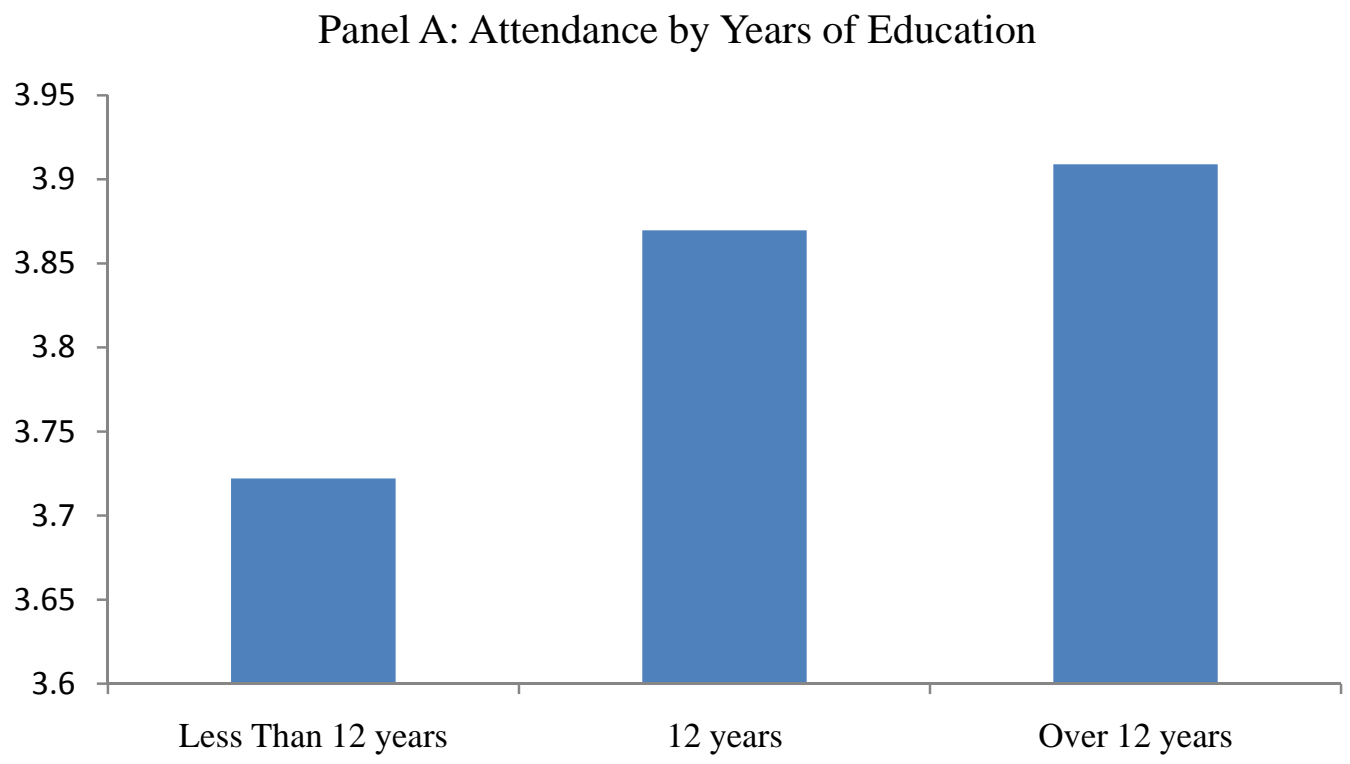

Panel B: Trends in Education and Religious Attendance

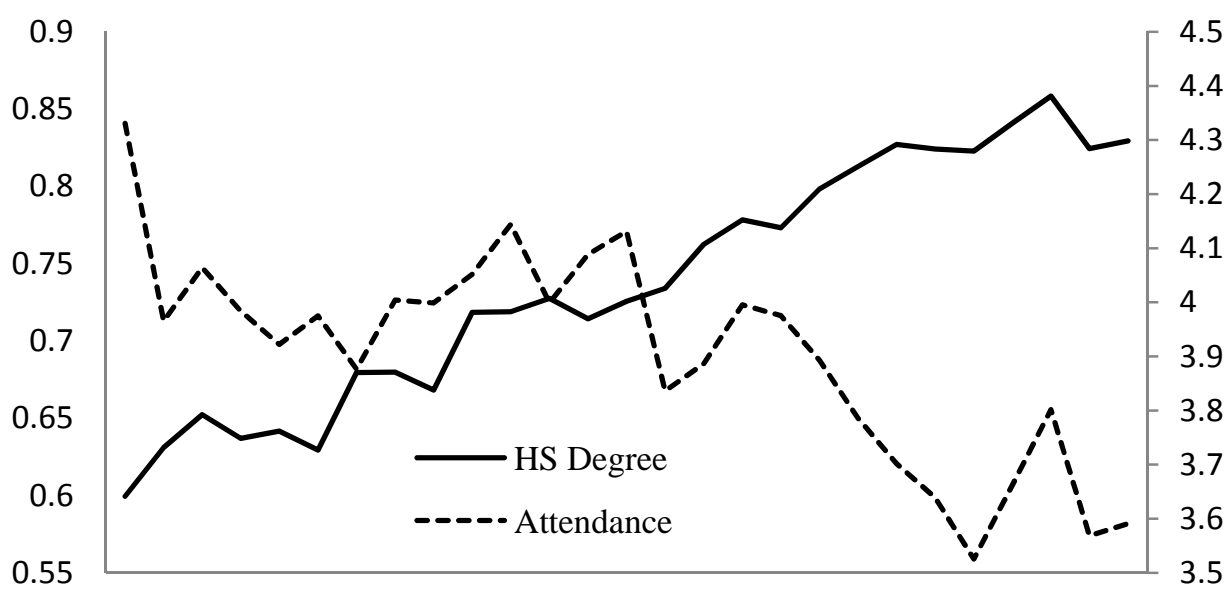

19721974197619781982198419861988199019931996200020042008

Source: GSS from 1972 to 2008. Panel A shows average attendance by years of educational attainment, panel B shows (a) the fraction of GSS respondents each survey year with a high-school degree, measured on the left axis, and (b) average attendance of GSS respondents each survey year, measured on the right axis. Attendance is measured on an index that goes from zero (never attend) to 8 (attend more than once a week). The mean of the index is 3.85 (standard error $=0.01$ ); corresponding to about monthly attendance. The index categories are 0 (never attend), 1 (less than once a year), 2 (once a year), 3 (several time a year), 4 (once a month), 5 (2 or 3 times a month), 6 (nearly every week), 7 (weekly), and 8 (more than once a week). 
Figure 2:

Cohort Educational Attainment and Non-affiliation in Quebec

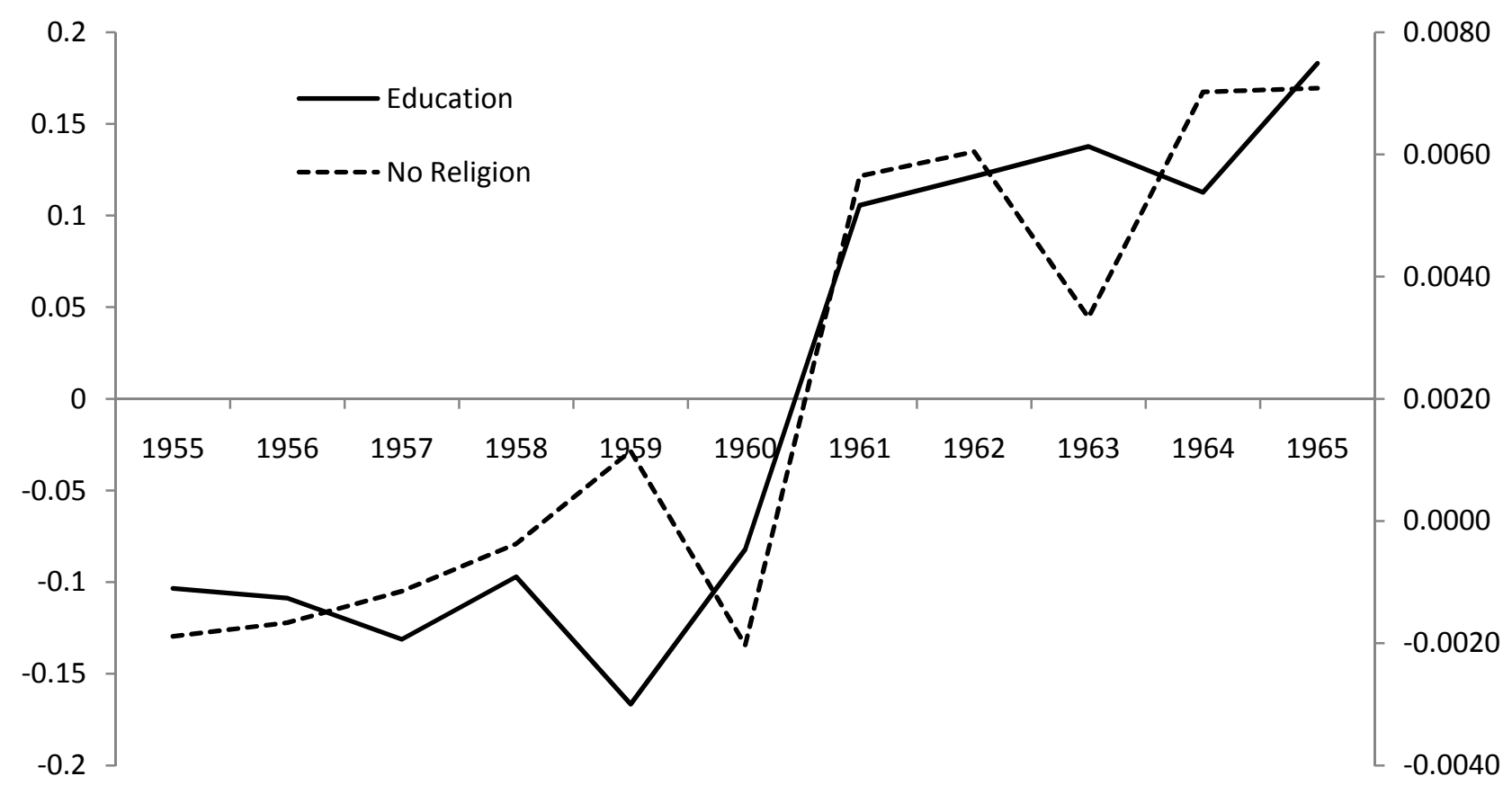

This figure shows two lines. The first is the average years of educational attainment for cohorts born in Quebec between 1941 and 1951, detrended. (Rather than birth year, the horizontal axis shows the year each cohort turned 14.) The second line shows the fraction of individuals reporting no religious affiliation in each cohort, detrended. In 1961 Quebec raised the minimum school leaving age to 15. The data are taken from the 1971, 1981, 1991, and 2001 Canadian Censuses. There are 85,829 individuals across these cohorts. There are two vertical axes in the picture, the left axis is for the education variable and the right axis is for the no-religion variable. 


\section{Figure 3: Pre-Existing Trends in Canadian Data}

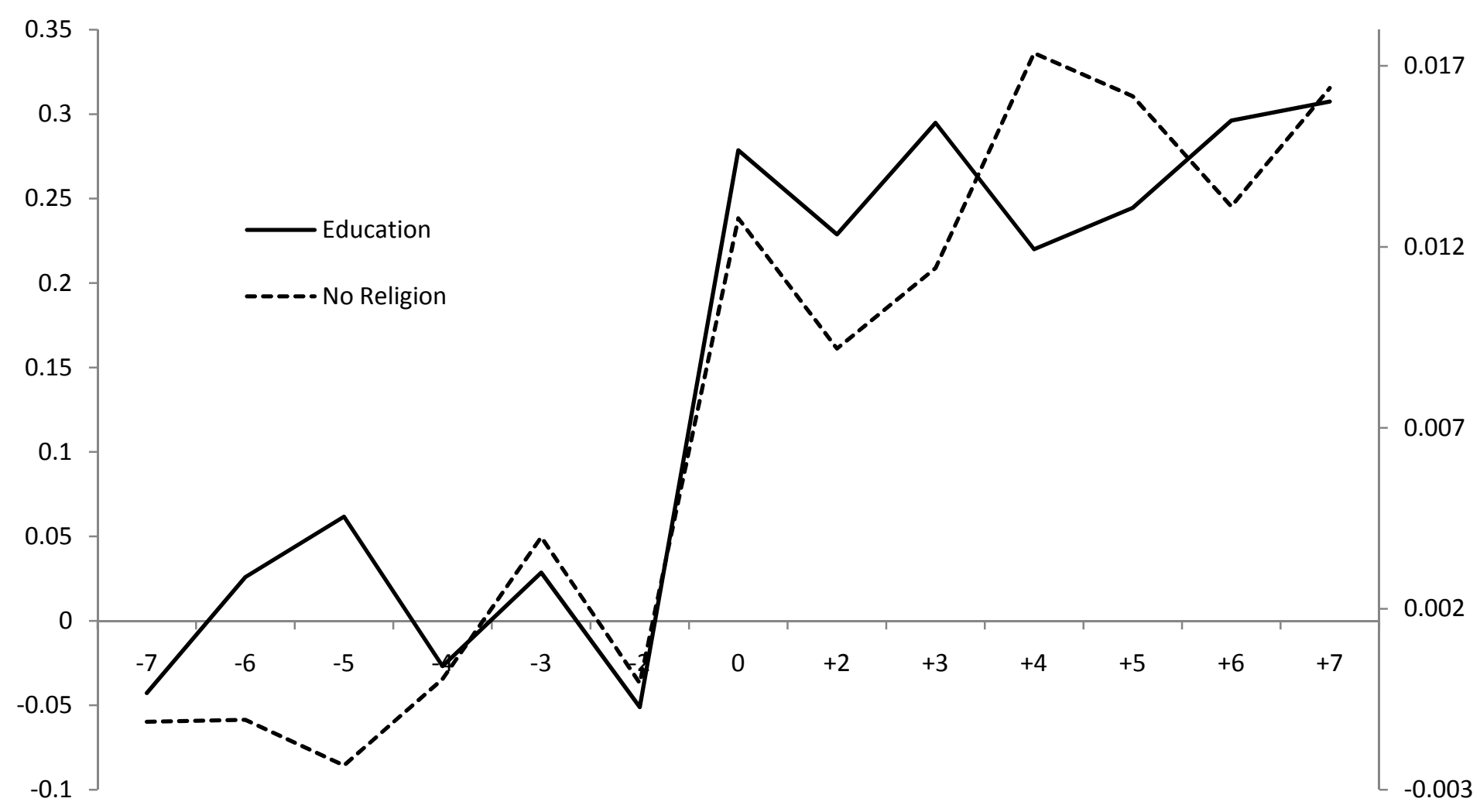

The figure shows the predicted impact of imposing a compulsory schooling age of 14 (relative to having no school leaving age) on (a) years of educational attainment and (b) fraction of individuals in a cohort reporting no religious affiliation in the census. The figure shows the predict values of these two variables from 7 years before a change in compulsory schooling laws to 7 years after the change. There are two vertical axes in the figure, the left axis is for the education variable and the right axis is for the no-religion variable. The predicted values for both variables are based on regressions described in the text. 
Table 1:

First-Stage Regressions on Educational Attainment

\begin{tabular}{|c|c|c|c|c|c|c|}
\hline & Baseline & $\begin{array}{c}\text { Extra } \\
\text { Controls } \\
\end{array}$ & No Quebec & Baseline & $\begin{array}{c}\text { Extra } \\
\text { Controls } \\
\end{array}$ & No Quebec \\
\hline School Leaving Age & $\begin{array}{c}0.0167 \\
{[0.0074]}\end{array}$ & $\begin{array}{c}0.0222 \\
{[0.0082]}\end{array}$ & $\begin{array}{c}0.0412 \\
{[0.0098]}\end{array}$ & - & - & - \\
\hline School Leaving Age $=12$ & - & - & - & $\begin{array}{c}-0.0069 \\
{[0.1758]}\end{array}$ & $\begin{array}{c}0.1089 \\
{[0.1839]}\end{array}$ & $\begin{array}{c}0.4624 \\
{[0.1908]}\end{array}$ \\
\hline School Leaving Age $=13$ & - & - & - & $\begin{array}{c}0.3497 \\
{[0.2678]} \\
\end{array}$ & $\begin{array}{c}0.2975 \\
{[0.2765]} \\
\end{array}$ & $\begin{array}{c}0.5545 \\
{[0.2813]} \\
\end{array}$ \\
\hline School Leaving Age $=14$ & - & - & - & $\begin{array}{c}0.3838 \\
{[0.1276]}\end{array}$ & $\begin{array}{c}0.4371 \\
{[0.1425]}\end{array}$ & $\begin{array}{c}0.6421 \\
{[0.1565]}\end{array}$ \\
\hline School Leaving Age $=15$ & - & - & - & $\begin{array}{c}0.4437 \\
{[0.1280]}\end{array}$ & $\begin{array}{c}0.4542 \\
{[0.1430]}\end{array}$ & $\begin{array}{c}0.7543 \\
{[0.1583]}\end{array}$ \\
\hline School Leaving Age $=16$ & - & - & - & $\begin{array}{c}0.2425 \\
{[0.1260]}\end{array}$ & $\begin{array}{c}0.3259 \\
{[0.1433]}\end{array}$ & $\begin{array}{c}0.6539 \\
{[0.1609]}\end{array}$ \\
\hline All RHS Controls? & No & Yes & Yes & No & Yes & Yes \\
\hline Province-Cohort Trends? & Yes & Yes & Yes & Yes & Yes & Yes \\
\hline Province-Age Trends? & Yes & Yes & Yes & Yes & Yes & Yes \\
\hline Province Dummies? & Yes & Yes & Yes & Yes & Yes & Yes \\
\hline Age Dummies? & Yes & Yes & Yes & Yes & Yes & Yes \\
\hline Cohort Dummies? & Yes & Yes & Yes & Yes & Yes & Yes \\
\hline Census Year Dummies? & Yes & Yes & Yes & Yes & Yes & Yes \\
\hline R-squared & 0.967 & 0.967 & 0.947 & 0.967 & 0.967 & 0.947 \\
\hline
\end{tabular}

Standard errors in brackets. The unit of observation is all individuals of a given gender, born in a given birth province, in a given cohort (i.e., birth year), reporting in a given census. The dependent variable is the average years of educational attainment; the mean of this variable is 10.7. Regressions in columns 1 , 2, 4, and 5 include 2,969 cells representing 755,386 respondents from the 1971, 1981, 1991, and 2001 Canadian Censuses. Regressions in columns 3 and 6 omit respondents born in Quebec and include 2,657 cells representing 497,721 individuals. The sample includes individuals over age 20 and turning age 14 between 1933 and 1977. Right-hand-side controls in all columns include the fraction of a province population that is rural, and the fraction of a province's workers in manufacturing at the time a respondent was 12 years old; columns 2, 3, 5, and 6 also include the log of school expenditures, schools per capita, and teachers per capita at the time a respondent was 12 years old. Regressions are weighted and standard errors are clustered by province and cohort. 
Table 2:

Reduced-Form Regressions on Religious Non-affiliation

\begin{tabular}{|c|c|c|c|c|c|c|}
\hline & Baseline & $\begin{array}{c}\text { Extra } \\
\text { Controls }\end{array}$ & No Quebec & Baseline & $\begin{array}{c}\text { Extra } \\
\text { Controls }\end{array}$ & No Quebec \\
\hline School Leaving Age & $\begin{array}{c}0.0014 \\
{[0.0005]}\end{array}$ & $\begin{array}{c}0.0013 \\
{[0.0005]}\end{array}$ & $\begin{array}{c}0.0014 \\
{[0.0005]}\end{array}$ & - & - & - \\
\hline School Leaving Age $=12$ & - & - & - & $\begin{array}{c}0.0038 \\
{[0.0097]}\end{array}$ & $\begin{array}{c}0.0043 \\
{[0.0104]}\end{array}$ & $\begin{array}{c}0.0163 \\
{[0.0127]}\end{array}$ \\
\hline School Leaving Age $=13$ & - & - & - & $\begin{array}{c}0.002 \\
{[0.0120]}\end{array}$ & $\begin{array}{c}0.0094 \\
{[0.0122]}\end{array}$ & $\begin{array}{c}0.0299 \\
{[0.0138]}\end{array}$ \\
\hline School Leaving Age $=14$ & - & - & - & $\begin{array}{c}0.0220 \\
{[0.0071]} \\
\end{array}$ & $\begin{array}{c}0.0190 \\
{[0.0067]}\end{array}$ & $\begin{array}{c}0.0202 \\
{[0.0074]}\end{array}$ \\
\hline School Leaving Age $=15$ & - & - & - & $\begin{array}{c}0.0223 \\
{[0.0075]}\end{array}$ & $\begin{array}{c}0.0219 \\
{[0.0073]}\end{array}$ & $\begin{array}{c}0.0406 \\
{[0.0099]}\end{array}$ \\
\hline School Leaving Age $=16$ & - & - & - & $\begin{array}{c}0.0191 \\
{[0.0076]}\end{array}$ & $\begin{array}{c}0.0170 \\
{[0.0076]}\end{array}$ & $\begin{array}{c}0.0281 \\
{[0.0101]}\end{array}$ \\
\hline All RHS Controls? & No & Yes & Yes & No & Yes & Yes \\
\hline Province-Cohort Trends? & Yes & Yes & Yes & Yes & Yes & Yes \\
\hline Province-Age Trends? & Yes & Yes & Yes & Yes & Yes & Yes \\
\hline Province Dummies? & Yes & Yes & Yes & Yes & Yes & Yes \\
\hline Age Dummies? & Yes & Yes & Yes & Yes & Yes & Yes \\
\hline Cohort Dummies? & Yes & Yes & Yes & Yes & Yes & Yes \\
\hline Census Year Dummies? & Yes & Yes & Yes & Yes & Yes & Yes \\
\hline R-squared & 0.919 & 0.919 & 0.912 & 0.919 & 0.919 & 0.912 \\
\hline
\end{tabular}

Standard errors in brackets. The unit of observation is all individuals of a given gender, born in a given birth province, in a given cohort (i.e., birth year), reporting in a given census. The dependent variable is the fraction of individuals reporting no religious affiliation; the mean of this variable is 0.085. Regressions in columns 1, 2, 4, and 5 include 2,969 cells representing 755,386 respondents from the 1971, 1981, 1991, and 2001 Canadian Censuses. Regressions in columns 3 and 6 omit respondents born in Quebec and include 2,657 cells representing 497,721 individuals. The sample includes individuals over age 20 and turning age 14 between 1933 and 1977. Right-hand-side controls in all columns include the fraction of a province population that is rural, and the fraction of a province's workers in manufacturing at the time a respondent was 12 years old; columns 2, 3, 5, and 6 also include the log of school expenditures, schools per capita, and teachers per capita at the time a respondent was 12 years old. Regressions are weighted and standard errors are clustered by province and cohort. 
Table 3:

IV Regressions on Religion

\begin{tabular}{|l|c|c|c|c|c|}
\hline & OLS & $\begin{array}{c}\text { IV-Non } \\
\text { Affiliation }\end{array}$ & $\begin{array}{c}\text { IV-Non } \\
\text { Affiliation }\end{array}$ & $\begin{array}{c}\text { IV-Catholic } \\
\text { Affiliation }\end{array}$ & $\begin{array}{c}\text { IV-Christian, } \\
\text { Non-Catholic }\end{array}$ \\
\hline Years of Education & -0.0084 & 0.0566 & 0.0437 & -0.0028 & -0.0402 \\
{$[0.0024]$} & {$[0.0240]$} & {$[0.0169]$} & {$[0.0293]$} & {$[0.0325]$} \\
\hline Weights? & Yes & Yes & Yes & Yes & Yes \\
\hline All RHS Controls? & Yes & Yes & Yes & Yes & Yes \\
\hline Province-Cohort Trends? & Yes & Yes & Yes & Yes & Yes \\
\hline Province-Age Trends? & Yes & Yes & Yes & Yes & Yes \\
\hline Province Dummies? & Yes & Yes & Yes & Yes & Yes \\
\hline Age Dummies? & Yes & Yes & Yes & Yes & Yes \\
\hline Cohort Dummies? & Yes & Yes & Yes & Yes & Yes \\
\hline Census Year Dummies? & Yes & Yes & Yes & Yes & Yes \\
\hline Instrument & NA & School & Leaving-Age & Leaving-Age & Leaving-Age \\
& Leaving Age & Dummies & Dummies & Dummies \\
\hline R-squared & 0.919 & 0.894 & 0.903 & 0.977 & 0.979 \\
\hline
\end{tabular}

Standard errors, clustered by province and cohort, in brackets. The dependent variable in columns 1,2 , and 3 is the fraction of a cohort that reports no religious affiliation. In column 4 the dependent variable is the fraction of respondents who report a Catholic affiliation, in column 5 it is the fraction who report a Christian, non-Catholic affiliation. Redoing columns 4 and 5 using a linear school-leaving-age instrument produces similar but less precise results. The unit of observation is all individuals of a given gender, born in a given birth province, in a given cohort (i.e., birth year), reporting in a given census. Regressions include 2,969 cells representing 755,386 respondents from the 1971, 1981, 1991, and 2001 Canadian Censuses. The sample is the same as in columns 2 and 4 of Table 2 and the right-hand-side controls are also the same. 
Table 4:

IV Regressions Dropping Each Province

\begin{tabular}{|l|c|}
\hline Province Dropped & $\begin{array}{c}\text { Coefficient } \\
\text { on Education }\end{array}$ \\
\hline Alberta & 0.0253 \\
& {$[0.0146]$} \\
\hline British Columbia & 0.0351 \\
& {$[0.0166]$} \\
\hline Manitoba & 0.0567 \\
& {$[0.0187]$} \\
\hline New Brunswick & 0.0385 \\
& {$[0.0182]$} \\
\hline Newfoundland & 0.0453 \\
& {$[0.0279]$} \\
\hline
\end{tabular}

\begin{tabular}{|l|c|}
\hline Province Dropped & $\begin{array}{c}\text { Coefficient } \\
\text { on Education }\end{array}$ \\
\hline Nova Scotia & 0.0463 \\
{$[0.0202]$} \\
\hline Ontario & 0.0435 \\
& {$[0.0162]$} \\
\hline Prince Edward Island & 0.0433 \\
& {$[0.0169]$} \\
\hline Quebec & 0.0474 \\
& {$[0.0133]$} \\
\hline Saskatchewan & 0.0547 \\
& {$[0.0196]$} \\
\hline
\end{tabular}

Standard errors, clustered by province and cohort, in brackets. Each regression matches the specification in column 3 of Table 3, except that here individuals born in a particular province are dropped from the sample. The dependent variable in all columns is the fraction of a cohort that reports no religious affiliation. The coefficient shown is for years of educational attainment, which is instrumented using a set of dummies for dropout age. 